\section{Dr. Wendling, et al reply}

\section{To the Editor:}

We read with interest the comment by Nagashima and Minota about our editorial ${ }^{1}$. We had mentioned the very interesting paper of our Japanese colleagues, reporting the first case of HBsAg-positive RA patient treated more than 5 years with an anti-interleukin 6 receptor monoclonal antibody (tocilizumab) $^{2}$. Indeed, antiviral therapy (entecavir) was added after 7 years of tocilizumab therapy. It is noteworthy, even if the patient was retrospectively diagnosed as $\mathrm{HBsAg-positive} \mathrm{with} \mathrm{high} \mathrm{viral} \mathrm{load} \mathrm{before}$ starting tocilizumab, that there was no evidence of exacerbation of hepatitis during these years of tocilizumab treatment, even without antiviral therapy for more than 5 years. This is of interest because interleukin 6 reduces HBV replication ${ }^{3}$, and tocilizumab may be able to reactivate viral infection, such as Epstein-Barr virus ${ }^{4}$.

This isolated and exceptional case is, of course, not a proof of safety of tocilizumab in every HBsAg-positive carrier, and we fully agree with the concluding comments of Nagashima and Minota, concordant with our previous statements about biologic agent use in this situation ${ }^{5}$. The longterm effects of antiviral therapy are unknown, and mutations and acquired resistance may occur, as shown in some cases with anti-tumor necrosis factor (anti-TNF) treatment in HBsAg-positive patients ${ }^{6}$. These considerations emphasize the need for systematic screening for HBV status in rheumatic diseases before starting biologic therapy with anti-TNF agents ${ }^{7}$, ritux$\mathrm{imab}^{8}$, and abatacept ${ }^{9}$; this is also the case for tocilizumab.

International guidelines ${ }^{10}$ suggest that in $\mathrm{HBsAg-positive} \mathrm{patients,}$ when immunosuppressive therapy is indicated, a preemptive treatment with lamivudine, entacavir, or tenofovir is required to prevent viral reactivation. This preemptive therapy should be given 7 days prior and maintained as long as the immunosuppressive treatment is present, and for 6 months after cessation. Tight control of transaminases and viral load is mandatory during treatment, and at least 3 months after discontinuation of the immunosuppressive agent.

DANIEL WENDLING, MD, PhD, Professor of Rheumatology, Head, Department of Rheumatology, University Teaching Hospital, and EA 3186, University of Franche-Comté, Besançon, France. Address correspondence to Dr. Wendling; E-mail: dwendling@chu-besancon.fr

\section{REFERENCES}

1. Wendling D, Di Martino V, Herbein G. Biologic agents in the treatment of rheumatic diseases with chronic viral infection. Where are we? [editorial]. J Rheumatol 2009;36:1107-8.

2. Nagashima T, Minota S. Long-term tocilizumab therapy in a patient with rheumatoid arthritis and chronic hepatitis B. Rheumatology 2008;47:1838-40.

3. Kuo TM, Hu CP, Chen YL, Hong MH, Jeng KS, Liang CC, et al. HBV replication is significantly reduced by IL-6. J Biomed Sci 2009; $16: 41$.

4. Ogawa J, Harigai M, Akashi T, Nagasaka K, Suzuki F, Tominaga S, et al. Exacerbation of chronic active Epstein-Barr virus infection in a patient with rheumatoid arthritis receiving humanised anti-interleukin-6 receptor monoclonal antibody. Ann Rheum Dis 2006;65:1667-9.

5. Wendling D, Herbein G. TNF-alpha antagonist therapy in patients with joint disease and chronic viral infection. Joint Bone Spine 2007;74:407-9.

6. Wendling D, Di Martino V, Prati C, Toussirot E, Herbein G. Spondyloarthropathy and chronic B hepatitis. Effect of anti-TNF therapy. Joint Bone Spine 2009;76:308-11.

7. Furst DE, Keystone EC, Kirkham B, Kavanaugh A, Fleischmann $\mathrm{R}$, Mease $\mathrm{P}$, et al. Updated consensus statement on biological agents for the treatment of rheumatic diseases, 2008. Ann Rheum Dis 2008;67 Suppl 3:iii2-25.

8. Pham T, Fautrel B, Gottenberg JE, Goupille P, Hachulla E, Masson $\mathrm{C}$, et al. Rituximab (MabThera) therapy and safety management. Clinical tool guide. Joint Bone Spine 2008;75 Suppl 1:S1-99.

9. Pham T, Claudepierre P, Constantin A, Fautrel B, Gossec L, Gottenberg JE, et al. Abatacept therapy and safety management. Joint Bone Spine 2009;76 Suppl 1:S3-S55.

10. Barclay S, Pol S, Mutimer D, Benhamou Y, Mills PR, Hayes PC, et al. The management of chronic hepatitis $B$ in the immunocompromised patient: Recommendations from a single topic meeting. J Clin Virol 2008;42:104-15.

J Rheumatol 2010;37:5; doi:10.3899/jrheum.091394 